\title{
GUIDED INQUIRY MODEL THROUGH VIRTUAL LABORATORY TO ENHANCE STUDENTS' SCIENCE PROCESS SKILLS ON HEAT CONCEPT
}

\author{
Gunawan $^{1 *}$, Ahmad Harjono ${ }^{2}$, Hermansyah ${ }^{3}$, \& Lovy Herayanti ${ }^{4}$ \\ ${ }_{1,2}^{1,2}$ niversitas Mataram, Indonesia, ${ }^{3}$ Universitas Samawa, Indonesia, ${ }^{4}$ IKIP Mataram, Indonesia \\ *e-mail: gunawan@unram.ac.id
}

\begin{abstract}
Science process skills are one of the indicators to know the level of achievement of physics teaching goals. This research examines the influence of guided inquiry models through virtual laboratories on students' science process skills. The research was a quasi-experiment conducted at the senior high school in Mataram, Lombok. The samples were class XI students, as many as 58 people divided into two sample groups: experimental and control groups. The guided inquiry model through the virtual laboratory was applied to the experimental group and the conventional model for the control group. The instrument used was a performance sheet. A t-test was used to analyze the effect of learning model on science process skill. The results of this study found that the achievement of science process skills for the experimental group was higher than the control group. The guided inquiry models through virtual laboratory have a significant effect on science process skills, especially on skills: hypothesizing, practicing, and communicating. These findings contribute significantly to the current knowledge about the effectiveness of guided inquiry models through virtual laboratories to improve students' science process skills in physics teaching.
\end{abstract}

Keywords: guided inquiry, virtual laboratory, science process skills, heat concepts

\section{MODEL INKUIRI TERBIMBING MELALUI LABORATORIUM VIRTUAL UNTUK MENINGKATKAN KETERAMPILAN PROSES SAINS SISWA PADA KONSEP KALOR}

\begin{abstract}
Abstrak: Keterampilan proses sains adalah salah satu indikator untuk mengetahui tingkat pencapaian tujuan pembelajaran fisika. Penelitian ini menguji pengaruh model inkuiri terbimbing melalui laboratorium virtual pada keterampilan proses sains siswa. Penelitian ini termasuk eksperimen semu yang dilakukan di Sekolah Menengah Atas di Mataram, Lombok. Sampel adalah siswa kelas XI sebanyak 58 orang yang dibagi menjadi dua kelompok sampel: kelompok eksperimen dan kontrol. Model inkuiri terbimbing melalui laboratorium virtual digunakan pada kelompok eksperimen dan model tradisional untuk kelompok kontrol. Instrumen yang digunakan adalah lembar kinerja. Uji beda t-tes digunakan untuk menganalisis pengaruh model pembelajaran terhadap keterampilan proses sains. Hasil penelitian ini menemukan bahwa pencapaian keterampilan proses sains untuk kelompok eksperimen lebih tinggi dibanding kelompok kontrol. Model inkuiri terbimbing melalui laboratorium virtual memiliki pengaruh yang signifikan pada keterampilan proses sains terutama pada keterampilan: berhipotesis, praktikum, dan berkomunikasi. Temuan ini berkontribusi signifikan terhadap pengetahuan saat ini tentang efektivitas model inkuiri terbimbing melalui laboratorium virtual untuk meningkatkan keterampilan proses sains siswa dalam pembelajaran fisika.
\end{abstract}

Kata Kunci: inkuiri terbimbing, laboratorium virtual, keterampilan proses sains, konsep kalor

\section{INTRODUCTION}

The essence of science is not only about the content but the process as well. Physics is a part of science that is closely related to how to analyze the natural phenomena systematically. Some physics concepts which are abstract concepts often become obstacles for teachers to convey and visualize concepts to students. Therefore, the teaching of physics is not only a collection of knowledge such as facts, concepts, or principles but is a process of discovery. Consequently, life skills are indispensable in social life to adapt and deal with the challenges of everyday life well. The development of life skills can be done by teachers at school (Khera \& Khosla, 2012). 
The purpose of physics teaching is to develop students' experiences in formulating problems, testing hypotheses through experiments, designing and assembling experimental instruments, collecting, processing and interpreting data, and communicating experimental results both orally and in writing. In addition, physics is taught so that students understand the concept well. Understanding good physics concepts can be a reference for students to solve various problems and interpret physics concepts. Therefore, an inquiry-based learning model or emphasis on student-centered skills and learning is needed (Crouch \& Mazur, 2001; Smith, Wood, Adams, Wieman, Knight, Guild, \& Su, 2009; Tien, Roth, \& Kampmeier, 2002). Additionally, Sheffield, \& McIlvenny (2014) stated that the inquiry could improve students' knowledge and confidence in the skills and processes related to questions and concepts of science.

The inquiry is a process for obtaining information. The information comes from the process of observation or experiment to find answers and solve problems using critical and logical thinking skills. The inquiry learning model provides more opportunities for students to learn directly. In addition, students have the opportunity to practice developing process skills, thinking skills, and being scientific (Jufri, 2013). Inquiry-based learning aims to encourage students to be more creative in imagining. The process of imagination in this model is organized and appreciated as a form of natural curiosity. Therefore, they are encouraged not only to understand the subject matter but also to create an invention. Furthermore, students are not only within the scope of discussing science learning but also encouraged to do science (Anam, 2015).

In principle, the purpose of inquiry learning helps students in formulating questions, seeking answers or solving to satisfy their curiosity, and helping to understand a theory or an idea of what is learned. Based on teacher guidance of students, the inquiry learning model was divided into three types: free inquiry, modified free inquiry, and guided inquiry. This study chooses guided inquiry model based on feedback from physics teacher that the students are still difficult to conduct an independent investigation, so still need teacher guidance.
Learning with a guided inquiry model involves students in finding and using various sources of information to improve their understanding of the concepts learned. Students not only answer questions and get correct answers but also involve interest and challenge students to connect their world with inquiry (Kuhlthau, Maniotes, \& Caspari, 2015). Students are required to find concepts through instructions from teachers. Teachers as mentors in the learning process need to support lowability students to learn well. As a result, highly skilled students do not monopolize learning.

This model is suitable to be applied in physics teaching. Furthermore, the syntax of the model can develop basic science skills that include: observing, classifying, computing, formulating hypotheses, designing experiments, measuring, collecting data, interpreting data, drawing conclusions, and communicating.

The skills of activities that have been described are known as skills in the process of science. Scientific process skills typically refer to skills the students possess such as scientists in the scientific discovery process. Scientific process skills are behaviours that encourage skills to acquire knowledge. In addition, disseminate such knowledge to improve mental and psychomotor skills optimally. Based on research by Turiman, Omar, Daud, \& Osman (2012), science process skills can train students in the process of thinking and scientific attitudes. The process of learning and teaching science process skills is a process designed in such a way that students understand facts, concepts, and relate them to the science process skill theories and the students' attitudes themselves. These skills are divided into two groups. First, basic science process skills include the process of observing, asking questions, classifying, measuring, and predicting. Second, integrated science process skills include: the process of identifying and defining variables, collecting and transforming data, creating data tables and graphs, describing the relationships between variables, interpreting data, manipulating materials, recording data, formulating hypotheses, designing investigations, summarizing and generalizing(Karamustafaoðlu, 2011). The basic skills of science can be applied through practicum activities.

The capabilities developed in the practicum should be student-oriented and product-oriented 
(Odubunmi \& Balogun, 1991). Therefore, learning through practicum should be clear about the specific scientific formulae that are rational and adapted to what the student needs. Odubunmi \& Balogun (1991) define the general and specific goals that should be achieved in the practicum: solving problems, using knowledge and skills in unusual situations, designing simple experiments to test hypotheses, using laboratory skills to present simple experiments, interpreting data, and providing rules about experiments.

Scientific process skills are one of the most important basic science skills of the $21^{\text {st }}$ century. However, these skills are not supported by facilities to develop such as the availability of tools and practicum materials. The facility is still limited because it is quite expensive. An experiment in science requires tools and materials. Successful experiments are dependent on the ability to choose and use the right tools effectively. Using tools and materials is an experience that students need to make new ideas. This is an essential requirement for students who are still at the concrete operational level.

Practicum activities take a long time. Meanwhile, the utilization of tools and laboratory materials in the laboratory is still not effective. There are some problematic physical materials to be practiced or visualized using real tools and materials. As a result, students' skills are low and not developed. The solution is through the use of virtual media such as a virtual laboratory. This media is widely available on the internet and the results of previous researchers. The use of computer technology is also proven beneficiary in improving learners' critical thinking skill (Rajagukguk \& Simanjuntak, 2015), verbal and figural creativities (Hamlen, 2009), improve the concept mastery of the student (Herayanti, Fuadunnazmi, \& Habibi, 2017), and learners ability to solve problems (Serin, 2011).

Çelik, Sarý, \& Harwanto (2015) also stated that the use of a simulation program has an advantage in explaining the experiment to increase the students' understanding of physics, providing good visualization, easy to operate, enhance the students' creativity, making physics easier, representing the physical phenomena in visual program, entertaining and useful for fluid simulation. Simulations in virtual laboratories could train students' thinking skills in developing ideas by combining image patterns and verbal communication in solving problems.

Currently, the role of teachers is limited as a facilitator or regulator in the classroom. With multimedia, students can repeat every learning material until they understand it naturally (Muslem \& Abbas, 2017). The virtual laboratory as a teaching media is an essential component of the learning system. Virtual learning is one of the ways for teachers to interact with students. Microscopic and macroscopic phenomena can be described on a certain scale through simulations so that they can be observed by students (Arista \& Kuswanto, 2018).

Previous researchers have suggested that the virtual laboratory is a tool to improve teacher quality by providing virtual devices, algorithms, and other devices within a specific scope. The goal is to develop problem-solving skills and control themselves according to their professional needs in the future. Jaya (2012) defines a virtual laboratory as an interactive environment for creating and conducting simulation experiments: a playground for experimenting. It consists of domain dependent simulation programs, experimental units, tools to operate the objects, and reference books. As a result, researchers combine guided inquiry models with a virtual laboratory to develop students' science process skills.

Previous research has suggested that the application of guided inquiry learning models through simulation media significantly influences primary students' science skills (Hayati, Hikmawati, \& Wahyudi, 2017). In addition, the inquiry model proved to improve student learning (Schneider, Krajcik, Marx, \& Soloway, 2002; Von-Secker \& Lissitz, 1999).

The combination of the guided inquiry model and virtual laboratory is still rarely done, especially if it is associated with students' science process skills. In addition, the effectiveness of this learning model for science process skills requires a better understanding, supported by detailed data and discussion. Thus, a clearer study is needed to explain the importance of using guided inquiry learning models through virtual laboratories, to mastering students' science process skills. The importance of a clear understanding of the use of this model will be a benchmark for technological-based learning innovations. 
The benefits provided by this study include a better understanding of guided inquiry learning models if supported by media such as virtual laboratories. Other benefits such as can be used as an alternative learning model for teachers in developing better science learning, especially physics. The results of the study can be used as a reflection to make innovations and renewal of learning models in order to improve the quality of learning physics. The main thing is to provide actual research data in the application of technology in learning, especially in improving students' science process skills.

The purpose of this study was to examine the effect of applying the guided inquiry model through a virtual laboratory to students' science process skills on the concept of heat. The analysis was carried out on each indicator of the science process skills tested.

\section{METHODS}

This research was a quasi-experiment to determine the effect of treatment on dependent variables under controlled conditions (Creswell $\&$ Creswell, 2017). The research was conducted in senior high school at Mataram, West Nusa Tenggara. The research population was all students of class XI of natural sciences as many as 148 students. The sampling technique was cluster-random sampling. Respondents were 58 people divided into two groups: experiment and control. In the experimental class had been taught using a guided inquiry model assisted by a virtual laboratory while in the control class taught with conventional learning, which was cooperative learning. The data of science process skills were collected during the learning process, which used student performance appraisal instruments.
The study was conducted from September 2016 to March 2018. Scientific process skills were intended for students' basic science skills such as skills in formulating problems, hypothesizing, practicing, summarizing, and communicating. The five indicators of science process skills were used as the basis for developing research instruments. So that the score produced by the research subject will explain the strength of their science process skills. Scoring techniques are based on classical completeness techniques on a scale of 0 to 100 . The data obtained must be normally and homogeneously distributed as a pre-requisite for being analyzed using the t-test to determine the effect of guided inquiry model through the virtual laboratory to science process skills.

\section{FINDINGS}

In this study, guided inquiry model through virtual lab was used to improve students' science process skill. The data from the result was homogenous and normal, which showed in Table 1.

Based on the analysis result in Table 1, the science process skill data meets the prerequisites for analysis. The t-test at a significant level of 0.05 was used to determine the difference of guided inquiry model through the virtual laboratory and the conventional learning to science process skills at experiment class and control class. Recapitulation of test results is presented in Table 2.

Table 2 gives the results which show that the scores for the model differences used are $\mathrm{F}$ $=18.556$ with a significance of $0.000<0.05$. It means that there was a significant difference in the skills of the science process between the

Table 1. Normality and Homogeneity Test for Science Process Skills

\begin{tabular}{cc}
\hline Analysis & Science Process Skills \\
\hline $\mathrm{N}$ & 58 \\
Significance level & 0.05 \\
Normality & 0.473 \\
Decision & $0.473>0.05$, Normally distributed \\
Homogeneity & 0.084 \\
Decision & $0.084>0.05$, Homogeneous variant \\
\hline
\end{tabular}

Table 2. Hypothesis Testing on Science Process Skills

\begin{tabular}{ccccc}
\hline Source & Sum of Square Type III & The Average Squared & F & Sig. \\
\hline Models & 1198.689 & 1198.689 & 18.556 & $\mathrm{p}<0.001$ \\
\hline
\end{tabular}


Table 3. The Comparison of Student Science Process Skills

\begin{tabular}{cccc}
\hline Groups & Average & The Highest Score & The Lowest Score \\
\hline Experimental & 87,72 & 98,00 & 70,00 \\
Control & 77,93 & 95,00 & 65,00 \\
\hline
\end{tabular}

Table 4. Hypothesis Testing on Each Indicator of Science Process Skills

\begin{tabular}{ccccc}
\hline Anova Test & \multicolumn{3}{c}{ Mann-Whitney U Test } \\
\hline $\begin{array}{c}\text { Formulating } \\
\text { Problems }\end{array}$ & Hypothesizing & Practicing & Concluding & Communicating \\
\hline $\mathrm{F}=.047$ & $\mathrm{Z}=-2.897$ & $\mathrm{Z}=-5.982$ & $\mathrm{Z}=-1.319$ & $\mathrm{Z}=-4.182$ \\
\hline Sig. & & \multicolumn{3}{c}{ Sig. } \\
\hline .830 & .004 & .000 & .187 & .000 \\
\hline
\end{tabular}

experimental and control groups. The significant difference was supported by the average score of the experimental group that is higher than the control group, which showed in Table 3.

Indicators of the experimental and control groups are presented in Figure 1.

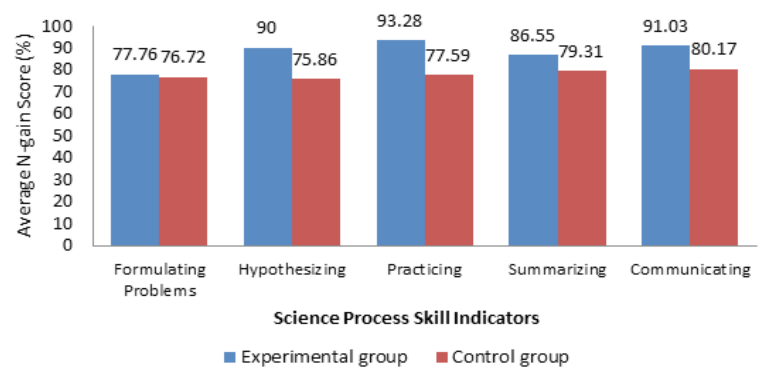

Figure 1. Comparison of Students' Science Process Skills on Each Indicator

The average score of the experimental and control group was similar in the first indicator: formulating the problem. For the other indicators, the scores were slightly higher on the experimental group than the control group. Hypothesis testing has been done for each indicator to know the significant difference of the score, and the result was showed in Table 4.

Data on the influence of guided inquiry model through the virtual laboratory on each indicator of the science process skills are presented in Table 4. The result showed that the first indicator of science process skill (formulating problem) had no significant difference score between the experiment and control group. Therefore, the findings indicated that the students' science process skills on indicators formulate problems almost the same in both groups. This result is supported by Mutlu
\& Sesen (2016), who found that virtual media did not affect to improve teacher skill in formulating the problem.

Based on Table 4, the $\mathrm{Z}$ value of the indicator making the hypothesis is -2.897 at a significant level of $0.004<0.05$. The average value for the experimental group was higher than the control. These results indicated that the guided inquiry model through the virtual laboratory has significantly influenced the students' skill in making hypotheses. Özgelen (2012) stated that making hypotheses or making statements about possible relationships is another essential skill based on accurate observations and conclusions. Interpreting data involves other process skills such as predicting, concluding, and hypothesizing the data collected. Students should have the experience to observe, classify, and measure before interpreting the data. The experiment involves all basic and integrated processes such as observing for the identification of variables, developing operational definitions, building and conducting tests, collecting and interpreting data, and modifying hypotheses.

On indicators of practicing and communicating based on Mann-Whitney U, test results obtained $Z$ values were: -5.982 and -4.182 on the significance of $0.000<0.05$. Therefore, there are significant differences for indicators of 'practicing and communicating between experimental and control groups. The experiment group average is higher than the control. Guided inquiry models through virtual laboratories exert a significant effect on students' science process skills for practicing and communicating indicators.

The fifth science process skill indicators, namely summarizing has no significant difference 
between experimental and control group. This result was proved by Mann-Whitney $U$ test results, which shows the value of $Z=-1.319$ at the level of significance of $0.187>0.05$. Although the average score of the experimental group was higher than the control group, statistically, the differences in the two groups were not significantly different.

\section{DISCUSSION}

Table 3 shows that students' science process skill was different for each group. The experimental group has a higher average score than the control group. This difference proves that guided inquiry model through a virtual lab can improve students' science process skill. Gormally, Brickman, Hallar, \& Armstrong (2009) found that the inquiry learning model through laboratories was better than the conventional model to improve students' science process skills. The students' scientific process skills are more effectively enhanced through virtual media, (Yang \& Heh, 2007; Mutlu \& Sesen, 2016) than the traditional laboratory. There was a difference in student activity before and after treatment in the application of guided inquiry model through a virtual laboratory. The guided inquiry learning model through the applied virtual laboratory has been able to prepare the students in situations to conduct experiments independently with teacher guidance. This learning model consists of learning stages to guide students through a series of scientific inquiries. Students become active in the learning process. However, in the conventional learning model, the application is tailored to the tools and laboratory that have been provided. As a result, students become passive in learning. Student activity during learning is mostly just sitting and listening to the teacher. Osman \& Vebrianto (2013) stated that learning with ICT can develop science process skills and simultaneously enhance the students' learning achievement. Ketpichainarong, Panijpan, \& Ruenwongsa (2010) stated that students' achievement in acquiring knowledge and science process skills was higher through inquiry laboratory than the traditional style. Mashami \& Gunawan (2018) stated that the results of experiments using computer simulation could improve students' critical thinking skills compared to students who do not use dynamic visualization elements in the classroom. These findings are supported by research by Minderhout \& Loertscher (2007), who developed a learningoriented guided learning process that enhanced content knowledge and student skills. The guided inquiry learning model through virtual laboratory is a student-oriented model. This model has learning stages that are used for training students' science process skills. The guided inquiry step is structured systematically and completely making the students active in the learning process. This study shows that students have the opportunity to improve the science process skills through investigation activities such as observation, formulating problems, hypnotizing, collecting data, testing hypotheses, and concluding. Each guided inquiry stage teaches students about the skills of the science process. The teacher prepares this learning model. The teacher guides the students to find and investigate the problem.

The control group was treated using a conventional learning model. Cooperative learning through the real experiment is used in the control class. Cooperative learning also has a good effect on improving students' science process skills in accordance with the research conducted by Bilgin (2006). However, students cannot control their learning time better. This is because the experimental process in the laboratory has high complexity. In addition to dealing with tools and long experimental methods, students are required to work together in groups, and many students perform other activities during the learning process such as talking to their friends, daydreaming and sleeping.

Furthermore, students in laboratory activities, run out of time in conducting experiments and could not complete all the procedures in it. As a result, it will impact on their lack of science process skills. This is the difference between the guided inquiry and conventional models. The advantage of guided inquiry through the use of virtual laboratories is to influence the skills of the science process. Olympiou \& Zacharia (2012) stated that the combination of real virtual laboratory aims to solidify the concepts obtained from real environments to be easily applied without losing the students' scientific process skills. The use of computer animation in virtual laboratories is useful for improving students' motivation and their desire to participate in laboratory activities (Karagöz \& Özdener, 2010). 
Overall, the guided inquiry model through the virtual laboratory does not have a significant effect on the skill indicators formulating the problemandmaking conclusions, while thismodel exerted a significant effect on hypothesizing, practicing, and communicating skills. According to Cahyani, Rustaman, Arifin, \& Hendriani (2014), multimedia-assisted inquiry learning can improve the attitude of curiosity, cooperation, creativity, and environmental awareness. The students' scientific ability, especially on conclusion capability and communicating ability, is higher than other indicators. Ismail, Permanasari, \& Setiawan, (2016) have found that the implementation of STEM-based virtual lab proved to improve student's scientific literacy. Prihatiningtyas, Prastowo, \& Jatmiko (2013) also found that the use of computer simulations and simple kits in physics teaching can help students complete learning outcomes on psychomotor aspects.

The students' science process skills were measured through a performance by applying the scientific methods presented in the student worksheet which include: creating goals, formulating the problem, hypothesizing, practicing, and communicating. The results of this study indicate that the group of students in the experimental group was better than the control in formulating the problem, which showed in Figure 1. However, the value of the experimental and control groups did not differ significantly. This is because there is no variation in the presentation of activity objectives as the basis of the students to make the problem formulation.

On the other hand, there were significant differences in the second indicators, namely hypothesizing. The model applied to the learning process is the activity of making the hypothesis. Nevertheless, the average value of the experimental group was higher than the controls on this indicator. The superiority of the experimental group in making the hypothesis is supported by the students' ability to formulate the problem. Students used the hypothesis to answer the problem formulation as a temporary answer before the practicum to test the hypothesis.

Meanwhile, the control group made the hypothesis not based on the formulation of the problems that have been prepared. As a result, the hypothesis is not to answer the problem formulation. In the data collection process, the experimental group was better than the control. Based on the results of the analysis of the practical skills, the experimental group was significantly different from the control group. The highest value of the experimental group is on the practicum indicator. The cause is a student skill formed through direct interaction with the virtual laboratory repeatedly to find the answer to the problem. It can train students in understanding the concept. Gunawan, Suranti, Nisrina, Herayanti, \& Rahmatiah (2018) have found that the use of virtual laboratory can help improve students' creativity in numerical, verbal, and figural aspects. Students' creativity in learning helps them to master the concept of physics better. This finding supports a study by Gunawan \& Liliasari (2012) reported that the computer technology is also proven beneficiary in improving learners' critical thinking disposition, specifically on two critical thinking disposition indicators, which is truth-seeking and openmindedness.

The experimental group was also better than the control in interpreting the data. The process of interpreting the data ends in a decision to conclude. This has been proven by the average score of the experimental group, which is higher than the control. However, the difference is not significant. There is no specific difference in skill-making conclusions between the experimental and control groups. The students' science process skills in communicating between the experimental and control groups differed significantly. The average score of the experimental group is higher than the control group. The advantage of the experimental group, in this case, is the ability to connect each stage that has been prepared.

\section{CONCLUSION}

The results of this study concluded that the guided inquiry model through the virtual laboratory has a significant effect on the students' science process skills. The average science process skills of the experimental group students were higher than the control groups in each indicator. In indicators hypothesizing, practicing, and communicating, abilities in both groups differed significantly. Whereas, the ability of both groups is almost the same on two indicators, namely formulating the problem and making conclusions. 
The findings of this study contribute to the development of the science of education, especially those related to the development of thinking skills and science process skills through learning assisted by computer technology. In further research, it is recommended that there be a measurement of the effectiveness of the inquiry model with virtual laboratories for 21 st-century thinking skills.

\section{ACKNOWLEDGMENT}

The author would like to extend their gratitude to the team at the Phytech Research Center, University of Mataram, for providing recommendations and corrections related to this article.

\section{REFERENCES}

Anam, K. (2015). Pembelajaran Berbasis Inkuiri: Metode dan Aplikasi. Yogyakarta: Pustaka Pelajar.

Arista, F. S., \& Kuswanto, H. (2018). Virtual physics laboratory application based on the android smartphone to improve learning independence and conceptual understanding. International Journal of Instruction, 11(1), 1-16. doi:10.12973/ iji.2018.1111a.

Bilgin, I. (2006). The effects of hands-on activities incorporating a cooperative learning approach on eight grade students 'science process skills and attitudes toward science. Journal of Baltic Science Education, 5(1), 27-37.

Cahyani, R., Rustaman, N. Y., Arifin, M., \& Hendriani, Y.(2014). Kemampuan kognisi, kerja ilmiah dan sikap mahasiswa non IPA melalui pembelajaran inkuiri berbantuan multimedia. Jurnal Pendidikan IPA Indonesia, 3(1), 1-4. doi: 10.15294/jpii. v3i1.2894

Çelik, H., Sarý, U., \& Harwanto, U. N. (2015). Developing and evaluating physics teaching material with algodoo (phun) in virtual environment: Archimedes' principle. International Journal of Innovation in Science and Mathematics
Education (formerly CAL-laborate International), 23(4), 40-50.

Creswell, J.W., \& Creswell, J.D. (2017). Research design: Qualitative, quantitative, and mixed methods approaches. Thousand Oaks, CA: Sage publications.

Crouch, C. H., \& Mazur, E. (2001). Peer instruction: Ten years of experience and results. AmericanJournalof Physics, 69(9), 970-977. doi:10.1119/1.1374249.

Gormally, C., Brickman, P., Hallar, B., \& Armstrong, N. (2009). Effects of inquirybased learning on students' science literacy skills and confidence. International Journal for the Scholarship of Teaching and Learning, 3(2), 1-22. doi:10.20429/ ijsotl.2009.030216.

Gunawan, G \& Liliasari L. (2012). Model virtual laboratory fisika modern untuk meningkatkandisposisiberpikirkritiscalon guru. Cakrawala Pendidikan, 31(2),185199. doi:10.21831/cp.v5i2.1556.

Gunawan, G., Suranti, N. M. Y., Nisrina, N., Herayanti, L., \& Rahmatiah, R. (2018). The effect of virtual lab and gender toward students' creativity of physics in senior high school. Journal of Physics: Conference Series, 1108(1), 012043. doi:10.1088/1742-6596/1108/1/012043.

Hamlen, K. R. (2009). Relationships between computer and video game play and creativity among upper elementary school students. Journal of Educational Computing Research, 40(1), 1-21. doi:10.2190/ec.40.1.a.

Hayati, S. N., Hikmawati, H., \& Wahyudi, W. (2017). Pengaruh model pembelajaran inkuiri dengan menggunakan media simulasi terhadap hasil belajar fisika siswa kelas X MIA SMAN 1 Lingsar Lombok Barat Tahun Pelajaran 2016/2017. Jurnal Pendidikan Fisika dan Teknologi, 3(1), 48-54. doi:10.29303/jpft.v3i1.323. 
Herayanti,L.,Fuadunnazmi,M.,\&Habibi.(2017). Pengembangan media pembelajaran berbasis moodle pada matakuliah fisika dasar. Cakrawala pendidikan, 36(2), 210219. doi:10.21831/cp.v36i2.13077.

Ismail, I., Permanasari, A., \& Setiawan, W. (2016). STEM Virtual Lab: An alternative practical media to enhance student's scientific literacy. Jurnal Pendidikan IPA Indonesia, 5(2), 239-246. doi:10.15294/ jpii.v5i2.5492.

Jaya, H. (2012). Pengembangan laboratorium virtual untuk kegiatan paraktikum dan memfasilitasi pendidikan karakter di SMK. Jurnal Pendidikan Vokasi, 2(1), 8190. doi:10.21831/jpv.v2i1.1019.

Jufri, W. (2013). Belajar dan pembelajaran sains. Bandung: Pustaka Reka Cipta.

Karagöz, Ö., \& Özdener, N. (2010). Evaluation of the usability of different virtual lab software used in physics courses. Bulgarian Journal of Science \& Education Policy, 4(2), 216235.

Karamustafaoðlu, S. (2011). Improving the science process skills ability of prospective science teachers using i diagrams. Eurasian Journal of Physics and Chemistry Education, 3(1), 26-38.

Ketpichainarong, W., Panijpan, B., \& Ruenwongsa, P. (2010). Enhanced learning of biotechnology students by an inquirybased cellulase laboratory. International Journal of Environmental and Science Education, 5(2), 169-187.

Khera, S., \& Khosla, S. (2012). Astudy of core life skills of adolescents in relation to their self concept developed through yuva school life skill programme. International Journal of Social Science \& Interdisciplinary Research, 1(11), 115-125.

Kuhlthau, C. C., Maniotes, L. K., \& Caspari, A. K. (2015). Guided Inquiry: Learning in the 21st century. Westport, CT: Libraries Unlimited.
Mashami, R. A., \& Gunawan, G. (2018). The influence of sub-microscopic media animation on students' critical thinking skills based on gender. Journal of Physics: Conference Series, 1108(1), p. 012106. doi:10.1088/1742-6596/1108/1/012106.

Minderhout, V., \& Loertscher, J. (2007). Lecture free biochemistry. Biochemistry and Molecular Biology Education, 35(3), 172180. doi:10.1002/bmb.39.

Muslem, A., \& Abbas, M. (2017). The effectiveness of immersive multimedia learning with peer support on English speaking and reading aloud. International Journal of Instruction, 10(1), 203-218. doi:10.12973/iji.2017.10113a.

Mutlu, A., \& ${ }^{a} e^{o} e n$, B. A. (2016). Impact of virtual chemistry laboratory instruction on pre-service science teachers' scientific process skills. In SHS Web of Conferences (Vol. 26, p. 01088). doi:10.1051/ shsconf/20162601088.

Odubunmi, O., \& Balogun, T. A. (1991).The effect of laboratory and lecture teaching methods on cognitive achievement in integrated science. Journal of Research in Science Teaching, 28(3), 213-224. doi:10.1002/tea.3660280303.

Olympiou, G., \& Zacharia, Z. C. (2012). Blending physical and virtual manipulatives: An effort to improve students' conceptual understanding through science laboratory experimentation. Science Education, 96(1), 21-47. doi:10.1002/sce.20463.

Osman, K., \& Vebrianto, R. (2013). Fostering science process skills and improving achievement through the use of multiple media. Journal of Baltic Science Education, 12(2), 191-204.

Özgelen, S. (2012). Students' Science process skills within a cognitive domain framework. Eurasia Journal of Mathematics, Science \& Technology Education, 8(4), 283-292. doi:10.12973/ eurasia.2012.846a. 
Prihatiningtyas, S., Prastowo, T., \& Jatmiko, B. (2013). Imlementasi simulasi PhET dan KIT sederhana untuk mengajarkan keterampilan psikomotorsiswa pada pokok bahasan alat optik. Jurnal Pendidikan IPA Indonesia, 2(1), 18-22. doi:10.15294/jpii. v2i1.2505.

Rajagukguk W., \& Simanjuntak, E. (2015). Problem-based mathematics teaching kits integrated with ict to improve students' critical thinking ability in junior high schools in Medan. Cakrawala Pendidikan,34(3), 347-356. doi:10.21831/ cp.v3i3.7342.

Schneider, R. M., Krajcik, J., Marx, R. W., \& Soloway, E. (2002). Performance of students in project based science classrooms on a national measure of science achievement. Journal of Research in Science Teaching, 39(5), 410-422. doi:10.1002/tea.10029.

Serin, O. (2011). The effects of the computerbased instruction on the achievement and problem solving skills of the science and technology students. Turkish Online Journal of Educational TechnologyTOJET, 10(1), 183-201.

Sheffield, R., \& McIlvenny, L. (2014). Design and implementation of scientific inquiry using technology in a teacher education program. International Journal of Innovation in Science and Mathematics Education, 22(6), 46-60.
Smith, M. K., Wood, W. B., Adams, W. K., Wieman, C., Knight, J. K., Guild, N., \& $\mathrm{Su}$, T. T. (2009). Why peer discussion improves student performance on in-class concept questions. Science, 323(5910), 122-124. doi:10.1126/science.1165919.

Tien, L. T., Roth, V., \& Kampmeier, J. A. (2002). Implementation of a peer led team learning instructional approach in an undergraduate organic chemistry course. Journal of Research in Science Teaching, 39(7), 606-632. doi:10.1002/tea.10038.

Turiman, P., Omar, J., Daud, A. M., \& Osman, K. (2012). Fostering the 21st century skills through scientific literacy and science process skills. Procedia-Social and Behavioral Sciences, 59, 110-116. doi:10.1016/j.sbspro.2012.09.253.

Von-Secker, C. E., \& Lissitz, R. W. (1999). Estimating the impact of instructional practices on student achievement in science. Journal of Research in Science Teaching, 36(10), 1110$1126 . \quad$ doi:10.1002/(SICI)10982736(199912)36:10\%3C1110::AIDTEA4\%3E3.0.CO;2-T.

Yang, K. Y., \& Heh, J. S. (2007). The impact of internet virtual physics laboratory instruction on the achievement in physics, science process skills and computer attitudes of 10th-grade students. Journal of Science Education and Technology, 16(5), 451-461. doi:10.1007/s10956-0079062-6. 